\title{
Belief, Certainty And Acceptance Therapy (Bcat)
}

\author{
Dr. Shadiya Mohamed Saleh Baqutayan \\ Perdana School of Science, Technology and Innovation Policy University technology Malaysia \\ International campus
}

\begin{abstract}
This paper presents a relatively new approach to the psychological treatment of individuals with cancer, namely, Belief, Certainty, and Acceptance Therapy (BCAT). This therapeutic approach is a spiritually and religiously treatment that firstly aims at believing on God wills, by making patients sense and feel God's ability to remove the harms from all being. Certainly, this therapeutic approach helps patients realize that when a person is inflicted with harm there is no one to remove it but God. As stated in the holy Quran (6:17) "And if Allah should touch you with adversity, there is no remover of it except Him". This belief come from human faith and their certainty that leads them accept any experience that he/she has no control over, and then take the action that is consistent with these beliefs. This is new therapeutic approach that might help the patients be satisfied with what they have been tested and then strengthen their spiritual coping strategies through accepting the disease and getting desirous toward God.
\end{abstract}

Keywords: Spirituality, Belief, Acceptance, Religiosity

\section{Introduction}

Historically, it has been difficult to find reliable medical evidence to prove that spirituality and religion methods work. Part of the blame for this might lie within the medical community's general unwillingness to see some of these methods as worthy of research. Therefore most of researchers focus in their study on medical methods to treat different types of diseases. However, the idea today is different; researchers start to focus on the importance of spiritual and religious therapy to deal with the physical and emotional problems of different patients. Thus, religion and spirituality play an important role in the treatment of different diseases including stress and anxiety (as our focus for this research). When a person is under stress and anxiety, chemicals build up their bodies and cause a host of problems, including sleeplessness, short temper, loss of appetite, digestive ills, memory loss, and many others. Spiritual healing can address the root issues that are causing stress in a person's life, and offer strategies to alleviate the stresses, or, at least, provide helpful coping mechanisms. By learning how to handle their anxiety on a spiritual level, many people find relief and better emotional well-being (Courtesy of Royalty Free Coaching Products).

Psychologist believed that the emotional treatment starts by developing with patient personal form of cognitive model that suite their individual anxiety disorder. In particular, the therapist aims to show cancer patients for example, how their specific anxiety produce negative automatic thoughts that leads to feared outcomes and how these are treated by different coping processes that suite their specific need. This research is working with cancer patients, and it is always a challenging due to the complexity of the situation. It requires different professionals jointly working with the patient. It is well known by researchers that the disease, which poses a threat to life, strikes and affects each involved person not only in his/her bio/psycho/social totality, but also equally in the spiritual sphere (Espíndula et al, 2010). Most of the study shows that patients rely on spiritual and religious issues to cope. In fact, spirituality/religiosity can be regarded as an important resource to cope, particularly for patients with cancer. In cancer patients, spirituality/religiosity may be beneficial for maintaining self-esteem, providing a sense of meaning and purpose, giving emotional comfort and providing a sense of hope (Thune-Boyle et al 2006).

Cognitive theorists propose that anxiety among cancer patient results from distorted beliefs about the dangerousness of certain disease, and the uncertainty of treatment. Consistent with this point, numerous studies have shown that patients with anxiety disorders over-estimate the dangerousness of various stimuli. Several studies have also shown that such over-estimates are disorder specific, with each anxiety disorder being associated with a particular type of negative belief (e.g. Harvey, Richards, Dziadosz, \& Swindell, 1993; Clark et al., 1997; Amir, Foa, \& Coles, 1998). As a result, effective counseling will be needed; the counselor who can help clients gain insight into the ways their core beliefs and values are reflected in their behavior; the counselor who can addresses the body, mind, and spirit. Though, the field of counseling has been slow in recognizing the need to address spiritual and religious concerns. But there is a great interest nowadays in the role of spirituality in both assessment and treatment of different patients.

Although religion and spirituality are sometimes part of the client's problem, but it can also be part of the client's solution. Because spiritual and religious values can play a major part in human life, spirituality 
should be viewed as a potential resource in therapy rather than as something to be ignored. Spirituality and religion are critical sources of strength for many clients, are the bedrock for finding meaning in life, and can be instrumental in promoting healing and well-being (Corey, 2008).

Professionals are still discussing the effectiveness of religious and spirituality on human well-being. For many patients confronted with chronic diseases, spirituality/religiosity is an important resource for coping. Patients often report unmet spiritual and existential needs, and spiritual support is also associated with better quality of life. Caring for spiritual, existential and psychosocial needs is not only relevant to patients at the end of their life but also to those suffering from long-term chronic illnesses. Spiritual needs may not always be associated with life satisfaction, but sometimes with anxiety, and can be interpreted as the patients' longing for spiritual well-being. Eventually, spiritual therapy is the only way to root out the seeds of pain from the minds of patients

Belief, certainty and acceptance therapy is new therapeutic approach in this research that is almost counseling approach. It deals more with the inner part of human being, by connecting the patient's heart, soul, and mind to God and making him accept the content of belief as true. Nevertheless, any external pressure as diseases for example in human life can change man's thinking and make them uncertain to accept the truth and reality. This therapeutic approach can deviate the clients thinking from being hopeless, uncertainty, and not accepting, to becoming strong and accepting the truth that God loves them and $\mathrm{He}$ is testing their faith through this disease. As a result, this counseling approach might reduce the anxiety feeling in all clients by helping them change their thoughts and behaviors toward their symptoms. So they can change the way they think and feel by learning how to reach the ultimate level of spiritual feeling. Patients will learn that God is the one who touches us with adversity, and there is no remover of it except Him. This belief come from the certainty that leads the person to accept any experience that he/she has no control over, and then take the action that is consistent with these beliefs. This might touch the feeling of the patients and help them decrease their depression. It is one of the few psychosocial treatments for depression that is shown to be effective in clinical trials. It has been shown to be as effective as anti- depressant medications for mild to moderate depressions in some clinical studies.

Belief, certainty and acceptance therapy (BCAT) is a system of assessing the subconscious mind and the soul to quickly find meaning to life problems and challenges that they are tested with, and then accept these challenges with loving, supportive ideas and beliefs. BCAT provides an exacting, powerful, virtually painless and accurate way of changing the landscape of patient inner and outer lives, enabling them to live their lives more freely. With BCAT, patients will learn how to be close and connected to the creature and how to belief and be certain on His mercifulness. So that he/she will accept the test of his creature and will ask cured from Him through the mean we have (medication). This theory is not only focusing on the spiritual medication but it will also encourage the physicians and medications, because both together can make patients achieve positive energy and inner peace.

History has recorded that Babur, Mugal Emperor of India, prayed for his son, Humayun's health who was seriously ill or almost near death. Hence Babur asked Allah (s.w.t) to spare his son's life and take his (Babur) life in lieu thereof (Syed, 2003). This story proofed what scientific research looking for. Most of the studies indicated that affirming belief in God makes a critical contribution to our physical health. When people call upon faith, they activate neurological pathways for self-healing. Therefore BCAT will help patients to look for God in order to achieve the self-healing.

Never before has the whole Muslim Ummah faced such fundamental challenges as we are facing today. Quran has forewarned Muslims of these and similar challenges. These warnings came in generic forms and it is our duty to identify the individual challenges and be aware of them. The Holy Quran highlighted the challenges that we face collectively, in several verses: (2:155-156)

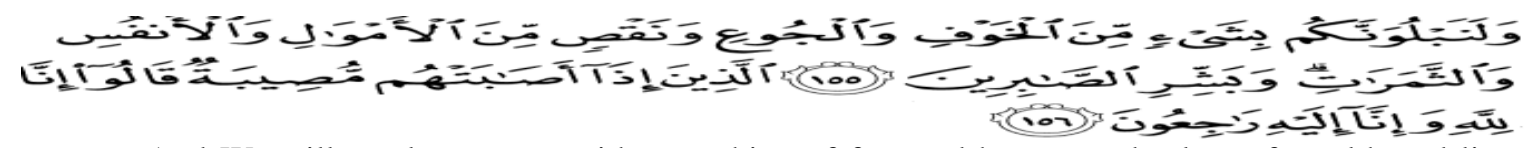

And We will surely test you with something of fear and hunger and a loss of wealth and lives and fruits, but give good tidings to the patient, Who, when disaster strikes them, say, "Indeed we belong to Allah , and indeed to Him we will return."

God will be testing all human being, because He wants to see how man can face and accept this test. Stated in the Quran (29:2), that

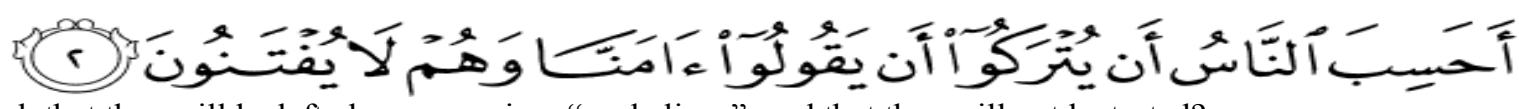

Do men think that they will be left alone on saying, "we believe", and that they will not be tested?

The Prophet (peace be upon him) said: "No fatigue, illness, anxiety, sorrow, harm or sadness afflicts any Muslim, even to the extent of a thorn pricking him, without Allah wiping out his sins by it." [Sahih alBukhari and Sahih Muslim] 
All sorts of difficulties such as sickness, lack of income, and disobedience from his children, may test the Muslim. The Prophet (pbuh) stressed this point, when he mentioned: "fatigue, illness, anxiety, sorrow, harm or sadness.... even to the extent of a thorn pricking him." All of these afflictions, if endured patiently by the believer, are a means of attaining Allah's forgiveness as well as His reward. It will guide us how to be close to God and accept what ever challenge we have. This will lead us to reach the ultimate level of being closeness to the almighty God. Quran (9:59).

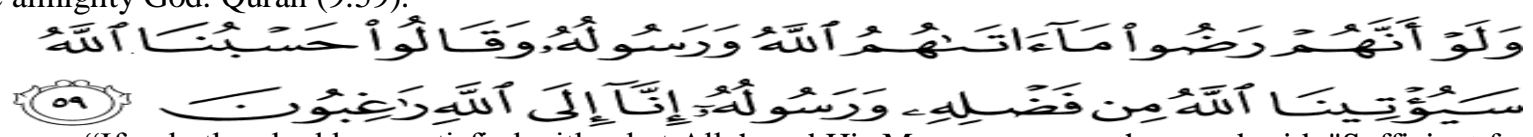

"If only they had been satisfied with what Allah and His Messenger gave them and said, "Sufficient for us is Allah; Allah will give us of His bounty, and [so will] His Messenger; indeed, we are desirous toward Allah," [it would have been better for them]".

Allah is testing every one. He tests us all in different ways. We should not assume, the difficulties we face in life are punishments or signs Allah is displeased with us. Likewise, we should never construe success, and the pleasures others enjoy, as signs Allah is pleased with them. Sometimes, quite the opposite is true. Quran $(67: 2)$.

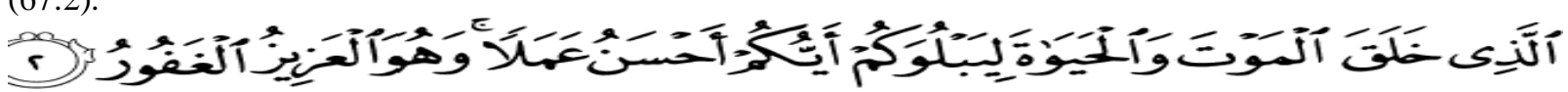

Allah says: "It is He who created death and life that He may try you as to which of you is best in deeds".

With support from the above verses Belief, certainty and acceptance therapy (BCAT) is strongly guides patients how to feel God, how to be close to Him, how to believe on Him, and how to accept His test. Researcher in this study observed the clients in different counseling sessions, and then indicated that the word God itself can makes the clients feel better. This is because God has great power and His name can makes the clients feel that power. Indeed, the power of God's name makes the heart, soul and mind calm and peace. Not only listening to God's name has impact on human mind, but also thinking on God's ability, mercifulness, loves, and kindness have great impact on client's psychology to overcome the emotional difficulties that he/she is having toward their sickness.

\section{Conclusion}

Belief, certainty and acceptance therapy (BCAT) is an approach that based on belief on God's will, certainty of his power in testing human being with different difficulties, healing the pain from them, and then accepting everything come from him. This therapeutic approach is a spiritually great treatment that aims to strengthen the patients' relation to God and make them feel better through believes on God's ability to remove the harms from all being. This kind of feeling healing approach might help the patients cope with their anxiety, depression, and stress that associated with different diseases.

\section{References:}

[1] Amir, N., Foa, E. B., \& Coles, M. E. (1998). Negative interpretation bias in social phobia. Behaviour Research Therapy, 36, 945-

[2] Clark, D. M.; Salkovskis, P. M.; Ost, L. G.; Breitholz, K. A.; Koehler, E.; Westling, B. E.; Jeavons, A.; \& Gelder, M. G. (1997) Misinterpretation of body sensations in panic disorder. Journal of Consulting and Clinical Psychology, 65, 203-213.

[3] Corey, G. (2008). Integrating Spirituality in Counseling Practice. Viewed on 3/4/2012,at http://counselingoutfitters.com/vistas/vistas06/vistas06.25.pdf

[4] Courtesy of Royalty Free Coaching Products. A Guide to Spiritual Healing. Viewed on 16/4/2012, at http://www.lifecoachwebsolutions.com/documents/newspiritualhealingReport.pdf

[5] Espíndula, J. A., Valle, E. R., \& Bello, A. A. (2010). Religion and Spirituality: the Perspective of Health Professionals. Rev. Latino-Am. Enfermagem, 2010 Nov-Dec;18(6):1229-36.

[6] Harvey, J. M.; Richards, J. C.; Dziadosz, T.; \& Swindell, A. (1993). Misinterpretation of ambiguous stimuli in panic disorder. Cognitive Therapy and Research, 17, 235-248.

[7] Koenig, H.G.; King, D.A.; \& Carson, V.B. (2011).The Handbook of Religion and Health, 2n ed.;Oxford University Press: New York, NY, USA, 2011.

[8] Syed, I. B. (2003). Spiritual medicine in the history of Islamic medicine. Journal of the International Society for the history of Islamic medicine 2, 2003, 45-49.

[9] The Noble Qur'an. Viewed on 16/4/2012 at http://quran.com/

[10] Thune-Boyle, I.C.; Stygall, J.A.; Keshtgar, M.R.; \& Newman, S.P. (2006). Do religious/spiritual coping strategies affect illness adjustment in patients with cancer? A systematic review of the literature. Soc. Sci. Med. 2006, 63, 151-164.

[11] Tuomela, R. (2000). Belief versus acceptance. Philosophical Explorations 2, 2000, 122-137). 